\title{
PENGARUH PENAMBAHAN SILICA FUME PADA KARAKTERISTIK GEOTEKNIK DAN KIMIA DARI LIMBAH PELABUHAN DALAM PENGGUNAANNYA PADA PEKERJAAN PEMBANGUNAN JALAN
}

\author{
Ernesto Silitonga \\ Dosen Pengajar Jurusan Pendidikan Teknik Bangunan, Fakultas Teknik Universitas Negeri Medan \\ (ernestosilitonga@unimed.ac.id)
}

\author{
Diterima : :23 Januari 2017 \\ Disetujui : :03 Maret 2017
}

\begin{abstract}
ABSTRAK
Peningkatan jumlah sedimen hasil pekerjaan pengerukan di Perancis setiap tahunnya.Semenjak diterapkannya peraturan mengenai limbah hasil pekerjaan pengerukan, pembuangan ke dalam laut tidak dianjurkan karena terbukti dapat menyebarkan polusi kedaerah sekitarnya.Penggunaan kembali dari limbah pelabuhan hasil pekerjaan pengerukan ini sangat perlu direalisasikan dengan segera.Tujuan utama dari penelitian ini adalah untuk menemukanbidang aplikasi reutulisasi dari limbah pelabuhan hasil pekerjaan pengerukan.Dalam upaya mengetahui apakah limbah pelabuhan tersebut dapat digunakan dalam pembangunan jalan, beberapa percobaan geoteknik dan kimia direalisasikan. Tujuan sekunder dari penelitian ini adalah untuk meningkatkan performa geoteknik dan mengurangi kadar polusi pada limbah pelabuhan sehingga dapat memenuhi kriteria dari pembangunan jalan dan aman terhadap lingkungan sekitar. Untuk memenuhi tujuan tersebut Silica Fume digunakan dalam penelitian ini.Beberapa percobaan geoteknik dan kimia direalisasikan dalam penelitian ini.Berdasarkan hasil yang didapatkan, Silica Fume sangat efektif dalam meningkatkan performa geoteknik dan memenuhi persyaratan geoteknik dalam pemgangunan jalan. Percobaan kimia (leaching test) direalisasikan dan hasilnya memperlihatkan bahwa pengaruh Silica Fume dalam campuran terbukti dapat mengurangi kadar polutan yang terkandung dalam limbah pelabuhan hasil pekerjaan pengerukan. Hasil percobaan ini memperlihatkan bahwa dengan penambahan Silica Fume, Limbah pelabuhan dianggap dapat digunakan sebagai material pengganti dalam pembangunan jalan dan aman bagi lingkungan sesuai dengan peraturan yang berlaku di Perancis.
\end{abstract}

Kata Kunci : Geoteknik, Limbah, Pelabuhan, Silica Fume

\begin{abstract}
Due to the increase of the amount of marine dredged sedimentsin France every year, especially with the European Environmental regulation established, environmentally reuse of dredged sediment is urgently needed in France. The first objective of this study is to find an application for reuse of marine dredged sediments materials, as a new material for road construction. Hence, serial tests need to be realized to identify if marine dredged sediment could be utilized for road construction. The second goal is to enhance the physical, mechanical and chemical characteristics of the mix, by incorporating binders and sediments, and revealed the identification of the mechanical characteristics measured on the mixes is compatible with their use as a base course material. The results show that the treatment by hydraulics binders could satisfy the needed mechanical characteristics. The present of Silica Fume is aimed to reduce the pollution level, especially the heavy metal content. However, the proportion of hydraulics binders and silica fume needed to meet prescribed specification is important, so the reuse of the marine dredged sediments of Port-en-Bessin, France in road construction, as an alternative material could be achieved. After the geotechnical study in laboratory results show as expected then the study to identify the chemical characteristic realized. To evaluate the environmental impacts of the used material, leaching test is
\end{abstract}


performed. The leaching test was performed to verify the predicted release of pollutants based on total dissolution.

Keywords: Geotechnical, Port, Silica Fume

\section{Pendahuluan}

Setelah masalah limbah pelabuhan di benua Eropah, khususnya Perancis, semakin meninggi, pemerintah Perancis menetapkan peraturan menyangkut pembuangan limbah hasil pekerjaan pengerukan. [1]. Peraturan ini melarang metode lama yaitu dengan membuang limbah pelabuhanke tengah laut.Tindakan membuang ke tengah laut ini menurut penelitian yang telah dilakukan sebelumnya terbukti dapat menyebarkan polusi ke lingkungan sekitar dan dapat merusak ekosistem dan bebrhaya bagi manusia.Sebelum menentukan apakah limbah pelabuhan tersebut dapat digunakan kembali, penting direalisasikan beberapa tes untuk mengevaluasi karakteristik limbah pelabuhan tersebut.

Beberapa penelitian dengan beragam metode untuk menemukan bidang aplikasi untuk reutulisasi dari limbah pelabuhan telah direalisasikan.Makalah ini berkonsentrasi untuk menemukan jenis dan komposisi yang tepat untuk menstabilisasi limbah pelabuhan. Silitonga menstabilisasi limbah pelabuhan hasil pekerjaan pengerukan dari pelabuhan Cherbourg (Basse Normandi, Perancis) [2].Penelitian ini meenggunakan kapur dan semen sebagai campuran, hasil penelitian memperlihatkan bahwa limbah pelabuhan setelah distabilisasi dengan kapur dan semen memperlihatkan peningkatan performa dan dapat memenuhi kriteria sehingga dianggap aman untuk digunakan sebagai material pengganti dalam pekerjaan pembangunan jalan.Javad pada penelitiannya menstabilisasi limbah pelabuhan hasil pekerjaan pengerukan dari pelabuhan Le Havre (Basse Normandie, Perancis) [3].Penelitian tersebut menggunakan kapur dan semen dalam upaya menstabilisasi limbah pelabuhan.Hasil penelitian memperlihatkan bahwa campuran yang menghasilkan performa terbaik berasal dari campuran dengan komposisi semen dan kapur sekitar $15 \%$.Abu terbang digunakan dalam campuran oleh Silitonga E., [4] dalam menstabilisasi limbah pelabuhan dari pelabuhan Cherbourg (Basse Normandie, Perancis).Komposisi ideal dari abu terbang yang diperoleh adalah sekitar 11\%.Hasil yang diperoleh memperlihatkan peningkatan signifikan diperoleh setelah 60 hari.Abu terbang dalam campuran terbukti dapat meningkatkan performa sehingga campuran dapat memenuhi kriteria yang diperlukan dalam pekerjaan jalan raya.Zhibo [5] dalam penelitiannya dalam menstabilisasi sedimen dari pelabuhan Cherbourg (Basse Normandie, Perancis) dengan menggunakan semen dan kapur memperlihatkan bahwa komposisi ideal dari terdiri dari $15 \%$ semen dan kapur didalam campuran.

Tujuan utama dari penelitian ini adalah untuk menyelidiki kemungkinan dari penggunaan limbah pelabuhan dalam aplikasinya sebagai material alternative dalam pekerjaan pembangunan jalan.Dalam upaya memenuhi persyaratan dalam pekerjaan pembangunan jalan, limbah pelabuhan harus melalui percobaan yang kerap dilakukan dalam pekerjaan pembangunan jalan. Masalah stabilisasi yang kerap ditemukan adalah apabila material yang akan digunakan terkontaminasi logam berat, selain dapat membahyakan bagi lingkungan sekitar dan manusia, kadar polutan dalam limbah dapat menghambat reaksi semen dan kapur dalam meningkatkan performa.Dalam upaya mencegah hal tersebut, maka dalam penelitian ini campuran yang digunakan untuk meningkatkan performa mekanik dan kimia adalah Silica Fume. Walaupun terkenal mahal akan tetapi Silica Fume secara teori memiliki kapasitas dalam meningkatkan performa mekanik dan menurunkan tingkat polusi dalam sedimen.

\section{Kajian Teori}

\subsection{Dredged Sediment and Silica Fume}

Penelitian ini direalisasikan dengan menggunakan limbah pelabuhan hasil pekerjaan pengerukan yang diambil dari pelabuhan Port en Bessin (Basse Normandie, Perancis) Pelabuhan Port en Bessin berada di bagian barat dari Perancis.Sedimen limbah pelabuhan tersebut diperoleh dari dau tempat 
berbeda, Bassin no.1 (PeB-1) dan Bassin no.2 (PeB-2).Jenis campuran yang digunakan dalam penelitian ini adalah semen, kapur dan Silica Fume.Hidrolik binder seperti semen dan kapur adalah jenis yang kerap dilakukan dalam pekerjaan pembangunan jalan.dalam penelitian ini dua tipe dari Silica Fume yang digunakan (FS1 dan FS2). Jenis Silica Fume yang digunakan dalam penelitian ini merupakan jenis yang belum diproduksi massal.Jenis Silca Fume ini merupakan prototip dari Silica Fume yang berasal dari sisa pembuatan Silica Fume yang diproduksi khusus untuk keperluan idnsutri beton.Silica Fume yang diharapkan dapat dijual dengan harga yang relative lebih rendah disbanding Silica Fume pada umumnya.Walaupun ukuran Silica Fume yang digunakan tidak sekecil disbanding Silica Fume pada umumnya. Hal ini dapat dilihat pada table 1 dan 3.

\subsection{Karakteristik Material}

\subsubsection{Ukuran Partikel}

Ukuran partikel dari sedimen limbah pelabuhan sangat kecil sehingga untuk merealisasikan identifikasi distribusi ukuran partikel digunakan alat laser diffractometer Coulter LS200 yang dapat mengidentifikasi ukuran partikel sampai dengan ukuran $<2 \mu \mathrm{m}$. Hasil percobaan identifkasi distribusi ukuran partikel dari sedimen limbah pelabuhan ini memperlihatkan bahwa ukuran dari sedimen limbah pelabuhan yang diambil dari emapt lokasi yang berbeda (PeB1, PeB2, PeB3 dan PeB4) tidak memperlihatkan perbedaan yang signifikan. Hasil ini memperlihakan homoginietas dari sedimen limbah pelabuhan ini.

Distriubusi ukuran partikel dari sedimen limbah pelabuhan dapat dilihat pada table 1. Hasil identifikasi distribusi partikel memperlihatkan bahwa majoritas partikel dari sedimen limbah pelabuhan berukuran antara 66,7- 78,4 $\mu \mathrm{m}$. Dari hasil identifikasi distribusi ukuran partikel dapat dilihat bahwa Silica Fume type 2 (SF2) memiliki ukuran yang lebih kecil disbanding Silica Fume type 1 (SF1). Menurut Silitonga dalam pekerjaan stabilisasi limbah pelabuhan dengan menggunakan abu terbang, bahwa hasil Unconfined Compressive Strength (UCS) cenderung menurun dengan meningkatnya ukuran partikel sedimen atau binder. Menurut penelitian sebelumnya yang dilakukan oleh Silitonga [7], bahwa partikel Silica Fume dengan ukuran lebih besar dari $45 \mu \mathrm{m}$ memiliki kecenderungan tidak terlalu reaktif dalam komdisi hidratasi normal. Reaksi Pozzolanik mencapai tingkat maksimum terjadi pada abu terbang dengan ukuran partikel dibawah $10 \mu \mathrm{m}$.

\subsubsection{Karakteristik Kimia}

Pengidentifikasian tingkat polusi dari sedimen limbah pelabuhan, sangat diperlukan dalam rangka menilai apakah limbah pelabuhan tersebut berbahaya bagi lingkungan sekitar atau manusia. Level polusi dari sedimen limbah pelabuhan diukur dengan merealisasikan percobaan Leaching.

Tabel 1 Ukuran partikel dari sedimen limbah Pelabuhan Port en Bessin.

\begin{tabular}{lcccccc}
\hline & PeB 1 & PeB 2 & PeB 3 & PeB4 & SF1 & SF2 \\
& & & & & & \\
\hline$<2 \mu \mathrm{m}(\%)$ & 10.7 & 10.6 & 13.8 & 9 & 2.3 & 13.8 \\
$2-63 \mu \mathrm{m}(\%)$ & 77.2 & 78.8 & 74.8 & 78.8 & 18.9 & 68 \\
$>63 \mu \mathrm{m}(\%)$ & 12.6 & 10.6 & 11.5 & 12.2 & 78.8 & 18.2 \\
\hline
\end{tabular}

Tabel 2 Hasil Percobaan Kimia (leaching test) Sedimen limbah hasil pengerukan

\begin{tabular}{cccccc}
\hline Pollutants & PeB 1 & PeB 2 & European Council Reference \\
\hline & & & $\begin{array}{c}\text { Inert } \\
\text { Waste }\end{array}$ & $\begin{array}{c}\text { Non } \\
\text { Hazardous } \\
\text { Waste }\end{array}$ & $\begin{array}{c}\text { Hazardous } \\
\text { Waste }\end{array}$ \\
\hline As $(\mathrm{mg} / \mathrm{kg})$ & 14 & 8.9 & 0,5 & 2 & 25 \\
\hline $\mathrm{Cd}(\mathrm{mg} / \mathrm{kg})$ & 1.33 & 1.59 & 0,04 & 1 & 5 \\
\hline $\mathrm{Cr}(\mathrm{mg} / \mathrm{kg})$ & 77 & 58 & 2 & 50 & 2 \\
\hline $\mathrm{Cu}(\mathrm{mg} / \mathrm{kg})$ & 1.41 & 0.63 & 0,01 & 0,2 & 2 \\
\hline $\begin{array}{c}\mathrm{Hg} \\
(\mathrm{mg} / \mathrm{kg})\end{array}$ & 0.63 & 0.73 & 0,01 & 0,2 & 100 \\
\hline
\end{tabular}




\begin{tabular}{cccccc}
\hline $\mathrm{Pb}(\mathrm{mg} / \mathrm{kg})$ & 20.2 & 17.9 & 0,5 & 10 & 50 \\
\hline $\mathrm{Ni}(\mathrm{mg} / \mathrm{kg})$ & 29.4 & 30.2 & 0,4 & 10 & 40 \\
\hline $\mathrm{Zn} \mathrm{(mg/kg)}$ & 137 & 148 & 4 & 50 & 200
\end{tabular}

Hasil percobaan Leaching dapat dilihat di tabel 2.Sampel untuk percobaan leaching ini diambil dari dua lokasi berbeda di Pelabuhan Port en Bessin yaitu PeB1 dan PeB2.Dalam upaya mengidentifikasi tingkat polusi peneliti menggunakan Peraturan menyangkut Managemen limbah hasil pengerukan yang ditetapkan oleh komite Eropah (European Council 2003/33/EC). Referensi ini membagi limbah hasil pengerukan kedalam 3 golongan yaitu; limbah bersih, limbah tidak berbahaya dan limbah berbahaya (Tabel 2)

Table 3. Karakteristik Kimia dari Silica Fume yang Digunakan

\begin{tabular}{|c|c|c|c|c|c|c|}
\hline Parameters & $\mathrm{SiO}_{2}$ & $\mathrm{Fe}_{2} \mathrm{O}_{3}$ & $\mathrm{AI}_{2} \mathrm{O}_{3}$ & $\mathrm{CaO}$ & $\mathrm{MgO}$ & $\mathrm{Na}_{2} \mathrm{O}$ \\
\hline \multicolumn{7}{|l|}{ Silica } \\
\hline $\begin{array}{l}\text { Fume } 1 \\
\text { (SF1) }\end{array}$ & $90-92$ & $1,5-2$ & 1 & $0,5-1$ & $1-1,5$ & $0,5-1$ \\
\hline Silica & & & & & & \\
\hline $\begin{array}{l}\text { Fume } 2 \\
\text { (SF2) }\end{array}$ & $90-95$ & $1.5-2$ & $1-1.5$ & $0,5-1$ & 1 & $0.8-1$ \\
\hline Parameters & $\mathrm{K}_{2} \mathrm{O}$ & $\mathrm{C}$ & free $\mathrm{Si}$ & $\begin{array}{l}\text { Free } \\
\mathrm{CaO}\end{array}$ & $\mathrm{SO}_{3}$ & \\
\hline \multicolumn{7}{|l|}{ Silica } \\
\hline $\begin{array}{l}\text { Fume } 1 \\
\text { (SF1) }\end{array}$ & $1-1,3$ & $0,5-1$ & $<0,2$ & $<1$ & $<1$ & \\
\hline Silica & & & & & & \\
\hline $\begin{array}{l}\text { Fume } 2 \\
\text { (SF2) }\end{array}$ & $\begin{array}{l}1.3- \\
1.5\end{array}$ & $1-1.5$ & $<0.4$ & $<1$ & $<1$ & \\
\hline
\end{tabular}

Nilai dalam referensi Eropah ini berkaitan dengan elemen yang terkandung dalam solusi yang digunakan pada percobaan Leaching bukan pada material original dari limbah pelabuhan hasil pengerukan. Table 3. memperlihatkan hasil percobaan kimia dari Silica Fume yang digunakan. Hasil percobaan memperlihatkan bahwa adanya perbedaan antara percentage $\mathrm{SiO}_{2}, \mathrm{Al}_{2} \mathrm{O}_{3}, \mathrm{MgO}, \mathrm{K}_{2} \mathrm{O}$ yang terkandung dalam Silica Fume. Silitonga dalam [7]dalam penelitiannya menyatakan bahwa karakteristik kimia dari material (limbah pelabuhan hasil pengerukan) sangat mempengaruhi performa mekanik dari hasil percobaan Unconfined Compressive Stregth (UCS). Hasil percobaan memperlihatkan bahwa SF2 memiliki persentase $\mathrm{SiO}_{2}, \mathrm{Fe}_{2} \mathrm{O}_{3}$ or $\mathrm{Al}_{2} \mathrm{O}_{3}$ lebih tinggi dari SF1, berdasarkan teori dapat dikatakan SF2 lebih reaktif disbanding SF1 dan akan memiliki performa mekanik lebih baik disbanding SF1

\section{Metodologi Penelitian}

\subsection{Preparation of Samples and Mix Design}

Setelah prosespengerukan dan pengambilan sedimen limbah, Percobaan geoteknik direalisasikan untuk mengidentifkasi karakteristik origin dari sedimen. Kadar air original dari sedimen adalah sekitar 169\%. Proses pengeringan direalisasikan untuk mengurangi kadar air dari sedimen hasil pengerukan, sehingga memungkinkan untuk dilakukannya proses stabilisasi. Proses pengeringan dilakukan dengan menggunakan bantuan tenaga matahari. Pada kondisi musim kemarau dengan Temperatur rata-rata sekitar 28-29 C, proses penegeringan memakan waktu sekitar 4-5 hari.Setelah mongering sedimen dipecahkan dan disaring dengan saringan $2 \mathrm{~mm}$. Berbagai campuran direalisasikan dengan komposisi yang berbeda-beda dengan tujuan untuk membandingkan kinerja dari setiap binder dengan persentase yang berbeda.Sampel direalisasikan dalam bentuk silinder dengan ukuran $(\varnothing=40 \mathrm{~mm}, \mathrm{~h}=$ $80 \mathrm{~mm}$ ).Sampel dicampur dengan dua tipe Silica Fume Samples dengan tujuan untuk dapat memperbandingkan perbedaan performa yang diciptakan oleh Silica Fume yang berbeda.

\section{Hasil dan Pembahasan \\ 4.1. Percobaan Daya Tarik}

Percobaan daya tarik merupakan salah satu percobaan yang paling penting untuk mengidentifikasi dari material untuk dapat digunakan sebagai material dasar dalam pembangunan jalan.Dalam penelitian ini Kekuatan Tarik direalisasikan disamping untuk mengidentifikasi kekuatan tarik yang didapat dengan menghitung modulus elastis yang diperoleh. Modulus elastis diperoleh dengan menggunakan kurva tegangan-regangan dari uji kompresi yang tidak terbatasi.

Pertama, kekuatan kompresi maksimum campuran diukur, kemudian modulus elastis, 

Dalam Penggunaannya Pada Pekerjaan Pembangunan Jalan

E, diukur pada sampel lain. Agar tidak merusak silinder, upaya maksimum yang diterapkan sesuai dengan $30 \%$ kekuatan kompresi maksimum.Hasil uji tarik ditunjukkan pada gambar 1.Seperti yang ditunjukkan pada gambar, hanya sampel dengan persentase Silika Fume sebesar 7\% yang berada di kelas S3 (G dan F). Menurut Skema ruas jalan dan karakteristik teknik yang direkomendasikan, sampel dengan kadar Silica Fume sebesar 7\% aman untuk digunakan sebagai material pada sub base dan pada pondasi.

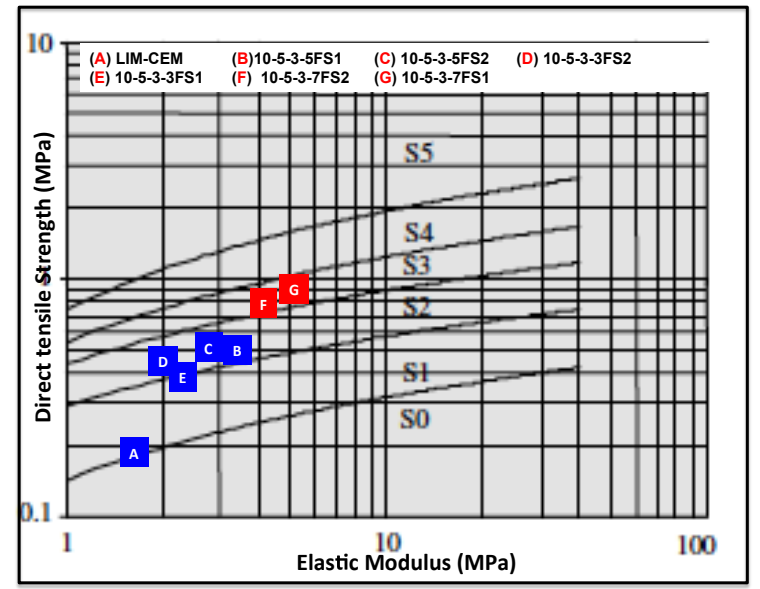

\section{Gambar 1 Hasil Percobaan Daya Tarik} (Tensil Strength)

Hasil penelitian menunjukkan bahwa, sampel dengan penambahan Silica Fume, menghasilkan Modulus elastisitas yang lebih tinggi dan nilai kekuatan tarik yang lebih tinggi dari pada sampel tanpa Silica Fume (LIM CEM). Sampel tanpa Silika LIM-CEM (A) terletak di dalam batas kelas S0 dan S1, artinya reutulisasi sedimen limbah pengerukan pada bagian sub basis perlu dipertimbangkan. Di sisi lain, sampel dengan Silica fume 3\% dan 5\% (B, C, D dan E) berada pada kelas yang sama (S2) namun nilai Modulus Elastis sampel dengan 5\% Silica Fume lebih tinggi dari pada sampel dengan 3\% Silica Fume. Secara teori, Silica Fume dengan efek pengisinya, disebabkan oleh ukuran partikel yang sangat kecilmaka partikel Silica Fume dapat masuk ke dalam dan mengisi ruang kosong antara butiran sedimen dan menghasilkan lebih banyak ikatan padat antara butiran sedimen, inilah alasan peningkatan Modulus Elastis, karena bahan yang lebih kaku akan memiliki Modulus elastisitas yang lebih tinggi. Hasil penelitian menunjukkan bahwa sampel dengan 3\% dan 5\% kadar Silica fume (B, C, D dan E) dapat digunakan sebagai bahan hanya di bagian sub basis. Di sisi lain sampel dengan $7 \%$ Silica fume $(\mathrm{H}$ dan $\mathrm{G})$ dapat digunakan kembali di bagian subbasis dan pondasi

\subsection{Percobaan Kimia}

Tujuan utama dari penelitian ini adalah untuk mengidentifikasi kemungkinan dari reutulisasi sedimen pengerukan laut sebagai material pengganti dalam konstruksi jalan yang dapat memenuhi kriteria peraturan jalan dan tidak berbahaya terhadap lingkungan.Namun, pada aplikasinya, diakibatkan proses pengeringan dan oksidasi endapan pengerukan laut tercemar dapat mempengaruhi mobilitas dan ketersediaan hayati lahan yang digunakan.Oleh sebab tersebut maka, Uji Lixiviation harus direalisasikan untuk mengidentifikasi kekuatan atau reaksi sampel terhadap lingkungan yang agresif, seperti perubahan $\mathrm{pH}$ yang ekstrim di lingkungan.

Uji Leaching direalisasikan menurut standar Prancis NF X 31-210 mengacu pada larutan yang mengandung unsur terlarut selama pengujian, yang dilakukan pada karakterisasi analisis.Untuk mengidentifikasi tingkat pencemaran sedimen dikeruk Port en Bessin, peneliti memutuskan untuk menggunakan nilai referensi yang ditetapkan oleh Dewan Eropa No. 2003/33 / EC. Menurut hasilnya. (Gambar 2), jumlah kadmium (cd) adalah 1,33 mg / kg, menurut referensi Eropa; Jumlah kadmium dikategorikan sebagai limbah non-berbahaya.Limbah non-berbahaya harus distabilisasikan terlebih dahulu hingga nantinya hasil memperlihaktan bahwa tingkat kontaminasi material dikategorikan dalam limbah bersih.

Hasil uji Leaching (gambar 2) menunjukkan bahwa, dalam kasus Kadmium (Cd), sampel dengan atau tanpa Silica Fume menunjukkan pengurangan kadar Kadmium. Sampel tanpa Silica Fume; LIM_CEM (B pada Gambar 2), menunjukkan sedikit pengurangan jumlah kadmium (dari 1,33 sampai 1,25) namun masih dalam tingkat pencemaran yang sama dengan jumlah polutan asli (tingkat limbah non-berbahaya).Semua sampel yang dicampur dengan 
Silica Fume memperlihatkan pengurangan yang sangat signifikan pada kadar persentase cadmium. Semua sampel dengan Silica Fume dikatergorikan pada Limbah bersih. Pengaruh jumlah persentase Silika Fume yang berbeda dapat dilihat pada Gambar 2.Sampel dengan persentase $3 \%$ Silica fume (C dan D) menunjukkan pengurangan minimal kandungan Kadmium dibandingkan sampel dengan 5\% (E dan F) dan 7\% Silica Fume (G dan $\mathrm{H}$ ). Sampel dengan $7 \%$ Silica Fume menunjukkan pengurangan yang sangat luar biasa dari kandungan Kadmium dan membentuk kelompok dengan jumlah kadmium terendah. Salah satu prinsip efek utama dari silica fume adalah sebagai pengisi, disebabkan oleh ukuran partikelnya yang sangat kecil, Silica Fume dapat masuk ke ruang antara butiran sedimen dengan cara yang sama seperti pasir dan mengisi ruang antara partikel agregat kasar dan butiran semen, mengisi ruang antara butiran pasir. Setelah reaksi pozzolan, Silica Fume mampu mengurung polutan, sehingga polutan tidak dapat lepas dari matriks dan mencemari lingkungan.Inilah alasan utama mengapa Silica Fume digunakan dalam penelitian ini.Jumlah pasir yang berbeda juga disadari dan bisa diperhatikan hasilnya.

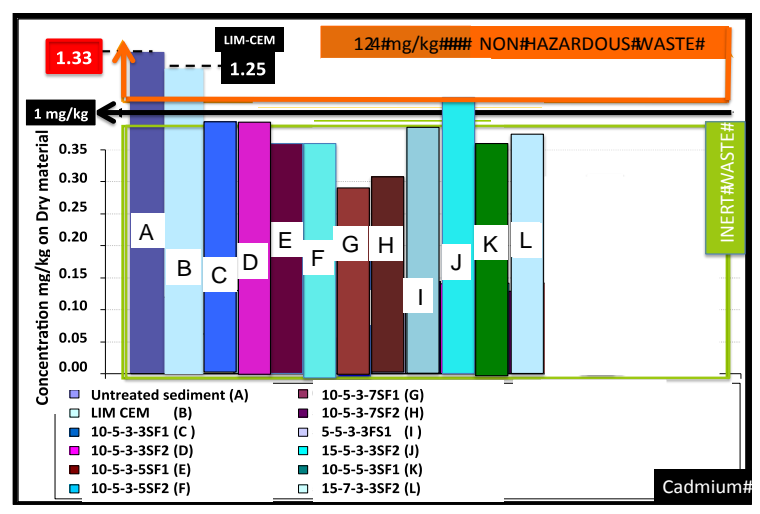

\section{Gambar 2 Hasil percobaan kimia untuk Kadmium (Cd}

Seperti ditunjukkan pada Gambar 2, kenaikan persentase pasir sampai $15 \%$ (J) hasil percobaan menunjukkan adanya peningkatan kandungan Kadmium jika dibandingkan dengan pasir $10 \%$ (D). Penambahan 15\% pasir, menyebabkan campuran ini dikategorikan dalam limbah bersih hingga limbah tidak berbahaya (referensi Dewan Eropa). Hasil penelitian menunjukkan bahwa kenaikan persentase semen dari 5\% sampai 7\% (L), dan persentase kapur dari 3\% sampai 5\% (K), dapat menurunkan kadar kadmium. Hasil ini disebabkan oleh hidrasi semen yang juga menghasilkan $\mathrm{Ca}(\mathrm{OH})$ 2, diperlukan untuk reaksi pozzolanic dalam Silica Fume dan untuk pertukaran ion dalam lempung, yang mempercepat reaksi semen dan pozzolanic asap Silica. Peningkatan reaksi semen / kapur dapat mendorong reaksi pozzolanic dari Silica sehingga menghasilkan reduksi kadar Kadmium. Menurut nilai referensi Eropa untuk sedimen pengerukan, dari sudut pandang lingkungan, setelah proses stabilisasi dengan 3\% to7\% asap Silica, sedimen pengerukan laut dikategorikan sebagai limbah bersih, sehingga tidak berbahaya bagi lingkungan dan dapat digunakan kembali sebagai bahan pengganti dalam pembangunan jalan

\section{KESIMPULAN DAN SARAN}

\subsection{Kesimpulan}

Tujuan utama dari penelitian ini adalah untuk memenuhi kriteria (sudut pandang geoteknik dan lingkungan) untuk reutulisasi dari sedimen limbah pengerukan yang tercemar logam berat, sebagai material pengganti pada konstruksi jalan. Percobaan identifikasi granulometrik menunjukkan bahwa endapan kerukan dari Port en Bessin membentuk partikel dalam jumlah besar dengan fraksi silt $(2-63 \mu \mathrm{m})$. Hasil uji pelindian menyatakan bahwa sedimen yang dikeruk dari kandungan Port en Bessin jumlah polutan dikategorikan sebagai limbah non-berbahaya (menurut European Reference).

Uji kekuatan tarik mengkonfirmasi bahwa sampel dengan penambahan $7 \%$ Silica fume dapat digunakan sebagai material di subbasis dan pondasi. Di sisi lain sampel dengan 3\% dan $5 \%$ Silica fume hanya bisa digunakan sebagai bahan pada bagian sub basis pada jalan raya. Percobaan kimia (leaching) memperlihatkan bahwa tambahan Silica Fume dalam spesimen (dari 3\% sampai 7\%) mampu untuk mengurangi jumlah polutan (kadmium) dan turun dari kategori limbah non-berbahaya menjadi limbah bersih. Oleh karena itu sedimen limbah pengerukan dengan persentase Silica fume sebesar 3\% -7\% dapat digunakan dalam pembangunan jalan dan tidak berbahaya bagi lingkungan. Di sisi lain, sampel tanpa 
Silica Fume (LIM_CIM) tidak dapat mengurangi kandungan Kadmium dan masih dikategorikan dalam limbah Non-Berbahaya. Hasil ini membuktikan alasan utama peneliti dalam menggunakan Silica Fume sebagai pengikat.Meski penggunaan biaya tambahan Silica Fume hasilnya menunjukkan bahwa Silica Fume mampu mengurangi kandungan polutan dalam sedimen

\section{Daftar Pustaka}

1. OSPAR Convention, Convention for the Protection of the Marine Environment of the North-East Atlantic, Paris (1992)

2. Silitonga E., Valorisation des sédiments marins contaminés par solidification/ stabilisation à base de liants hydrauliques et de fumée de silice. Thesis doctorat Université de Caen, France, 160p, (2010)

3. J. Behmanesh. Behmanesh J. ; Etude de la durabilité d'un sédiment, traité au ciment et additifs, Thèse de doctorat de l'Université de Caen. 214p (2008)

4. Silitonga E., Levacher D., Mezazigh S., Effects of theuse of fly ash as a binder on the mechanical behavior of treated dredged sediments, Environmental Technology vol 30. (2009)

5. Zhibo D. Caractérisation, stabilisation et solidification de sédiment marin. Thèse de doctorat, Université de Caen, 145p (2008)

6. E. Silitonga, D. Levacher, S. Mezazigh, Utilization of fly ash for stabilization of marine dredged sediment (2010), Revue Européenne de Génie Civil et Environnement Vol 14 Issue 2, p 253-265, (2010)

7. Gleize P.J.P., Müller A., et Roman H.R., (2003). Microstructural investigation of a silica fume - cement -lime mortar, Cement and Concrete composites, Vol.25, pp.171175.

8. European Standard, NF EN 14227-3, Hydraulic bound mixtures. Specifications. Fly ash bound mixtures. European Committee (2004).

9. Colin, D., Valorisation de sediments fin de dragage en technique routière. Thesis doctorat, Université de Caen, France, 181p (2003)

K. Siham, B. Fabrice, A. Nor Edine, D. Patrick, Marine dredged sediment as new material source for road construction, Waste Manaegement no.28 (2008) 919-218. 